Враховуючи наведене можна зробити висновок, що головним кластеротвірним чинником $є$ узгодженість дій регіональних органів влади щодо впровадження політики регіонального розвитку у сфері міжрегіональної інтеграції. Це зумовлює активізацію наукових пошуків у галузі науки публічного управління, спрямованих на удосконалення регіонального розвитку.

\title{
Література:
}

1. Маршалл А. Принципы экономической науки. - М.: Прогресс, 1993. - $594 \mathrm{c}$.

2. Krugman P. R. Geography and Trade. Cambridge, MA: MIT Press, 1991. $-156 \mathrm{p}$.

3. Портер М. Ю. Конкуренция. - М.: Издат. дом «Вильямс», 2005. $-608 \mathrm{c}$.

4. Solvell O. Clusters - Balancing Evolutionary and Constructive Forces. Stockholm: Ivory Tower Pub., 2009. - P. 17.

DOI https://doi.org/10.30525/978-9934-26-045-2-6

\section{ДИФЕРЕНЦІЙОВАНА ІНТЕГРАЦІЯ \\ В ЄС ЯК СПОСІБ ЗАБЕЗПЕЧЕННЯ НАДНАЦІОНАЛЬНОЇ УПРАВЛІНСЬКОЇ СТІЙКОСТІ ПІСЛЯ ВRЕХІТ}

\author{
Кривцова О. М. \\ кандидат наук з державного управління, \\ доиент кафедри глобалістики, \\ євроінтеграції та управління національною безпекою \\ Одеського регіонального інституту державного управління \\ Національної академії державного управління \\ при Президентові України \\ м. Одеса, Украӥна
}

Безперервні дебати щодо диференційованої інтеграції в ЄС отримали новий імпульс, викликаний рішенням британців 23 червня 2016 року залишити об'єднання 28 країн. В результаті ми стали свідками появи діаметрально протилежних прогнозів про наслідки Брекзіту та його вплив на ступінь диференціації в європейському інтеграційному процесі. На одному полюсі цих думок знаходиться 
твердження про те, що в результаті СС зіткнеться з більш глибокою диференціацією, оскільки Брекзіт, по суті, виявився відповіддю на відмову європейської бюрократії підтримувати особливі вподобання i виключення для окремих країн-членів в реалізації загального євроОінтеграційного проекту, тим самим підкресливши негативні наслідки такої наднаціональної політики. $[1,2,3]$. Протилежний підхід передбачає майбутнє ослаблення диференціації, оскільки його прихильники вважають, що Брекзіт усуває значну частку існуючих винятків в Союзі, вказує на слабкі політичні переваги нормативних вилучень на користь окремих держав і сприяє більшій єдності цілей 27 країн $Є С$ [4, 5]

Вищевідзначені прогнози щодо радикальної зміни перспектив диференціації в Свропейському союзі, на наш погляд, дещо передчасні. Брекзіт - недостатня умова для стимулювання реформ, які виведуть на чільне місце інтеграційного процесу такі форми диференціації як, наприклад, «Европа різних швидкостей», але в той же час вихід Британії з СС, безперечно, є стримуючим фактором для стимулювання різноманітних форм участі третіх країн в європейських інтеграційних ініціативах. 3 виходом Великобританії диференціація в $\mathrm{CC}$ не зникне i не втратить своєї актуальності, оскільки попит на особливі умови i виключення для «відстаючих» залишиться високим, особливо з огляду на те, що в певному сенсі на карту поставлена подальша доля європейського інтеграційного проекту в цілому .

Диференціація буде впроваджуватися у міру матеріалізації вимог стосовно індивідуальних винятків в рамках конкретних сфер загальної політики, де деякі країни-члени захочуть більш просувати спільні проекти (наприклад, безпека і оборона). Тобто, швидше за все, після Брекзіта диференціація в СС не зазнає радикальних змін.

В даний час диференціація відноситься до (зростаючого) набору винятків, але протягом багатьох років звучали наполегливі заклики «підвищити» iï до основного принияиу європейської інтеграції, включаючи 1) пропозиції щодо формування «двошвидкісної» або «багатошвидкісної» Свропи, де різні держави-члени просуваються в інтеграційному процесі з різною швидкістю; 2) пропозиції щодо «Свропі àla carte», в яких країни можуть вибирати окремі сфери політики, де вони вважають за краще брати участь, 3) і аналогічні пропозиції, засновані на «змінній геометрії», в яких групи країн могли б вибірково співпрацювати в окремих напрямах політики [6]. Форми можуть відрізнятися за деякими аспектами, але покладений в основу диференціації принцип різного ставлення до різних країн (або регіонів), піднімає загальні питання ефективності та політичної й управлінської стійкості ЄС. 
Прихильники диференціації стверджують, що вона може допомогти підвищити ефективність управління [7]. Наприклад, з огляду на різноманітність економічних моделей в Свропі, диференціація дозволяє уникнути «гамівної сорочки», що властива застосуванню загальних правил СС до різних національних умов [4]. Диференціація також дозволяє державам-членам визначати свій внесок у поглиблену співпрацю відповідно до їх конкретної спеціалізації, що призводить до більш ефективного розподілу праці [8]. Політична вигода диференціації, на думку деяких авторів, полягає в тому, що дозволяє непокірним державам-членам не робити «складні кроки», тим самим не підриваючи процес інтеграції зсередини. Без диференціації «інтеграційні угоди не виходили б за рамки уподобань держави-члена, найбільшою мірою орієнтованої на статус-кво» [3].

Цінність диференціації полягає не тільки в подоланні короткострокового спротиву, але і в посиленні тиску на норовливі держави-члени з метою зміни в довгостроковій перспективі їх уподобань (лояльності) [9]. Такий тиск, що націлений на приєднання до групи, може включати в себе ефекти «speel-over» (переливу) з інших областей політики та свідчення щодо переваг, одержуваних членами групи у вигляді «відокремлених мереж і «клубних» товарів» [10].

Однак, як стверджують критики, диференціація може бути неефективною. Неучасть означає ухилення від реалізації спільних політик, які складно регулюються, i рішення держави-члена про їх ігноруванні часто грунтується на політичних міркуваннях, при цьому мало уваги приділяється тому, як це може вплинути на формування загальної комунітарної політики у відповідній галузі. Держави-члени можуть відмовитися від співпраці в тих сферах політики, в яких їх участь може принести реальну користь інтеграційному процесу в цілому. Більш того, диференціація з заплутаним набором політик, що частково збігаються та чітким набором різних механізмів управління веде до ускладнення інтеграційної взаємодії $[11,12]$ Поширення нових форматів інтеграції в останні роки тільки посилює цю складність [9].

Політичні переваги диференціації також можуть не матеріалізуватися. Держави-члени, які не відповідають умовам участі можуть відчувати себе виключеними, що може привести до зниження солідарності замість зусиль, спрямованих на те, щоб «наздогнати держави-лідери». Невдоволення може виникати у держав, які виступають за інтеграцію, але не хочуть просуватися вперед в певних областях політики, «породжуючи у країни відчуття виключення 3 інтеграційного процесу, в якому вони дійсно хочуть брати участь» [9]. Окремо необхідно зазначити, що в тих випадках, коли треті країни 
приймають політику $\mathrm{CC}$, виникає реальний дефіцит демократії, оскільки у них відсутні неформальні і формальні канали впливу, необхідні для участі у справжньому ефективному управлінні $[12$, с. 10].

\section{Література:}

1. Burk M., \& Leuffen D. On the Methodology of Studying Differentiated (Dis)integration: Or How the Potential Outcome Framework Can Contribute to Evaluating the Costs and Benefits of Opting In or Out Journal of Common Market Studies. 2019. № 57(6). P. 1395-1406. URL: https://doi.org/10.1111/jcms.12958 (дата звернення: 25.02.2021)

2. De Witte B. An undivided Union? Differentiated integration in postBrexit times. Common Market Law Review. 2018. № 55(2-3). P. 227-250.

3. Schimmelfennig F. Brexit: Differentiated Disintegration in the European Union. Journal of European Public Policy, 2018. № 25(8). P. 1154-1173. URL: https://doi.org/10.1080/13501763.2018.1467954 (дата звернення: 16.02.2021)

4. Bickerton C. The limits of differentiation: capitalist diversity and labour mobility as drivers of Brexit. Comparative European Politics. 2019 № 17(2). P. 231-245.

5. Riedel, R. Great Britain and Differentiated Integration in Europe. Troitiño, D.R., Kerikmäe, T. \& Chochia, A. (eds) Brexit: History, Reasoning and Perspectives. 2018. Springer: Cham.

6. Stubb A.C. A Categorization of Differentiated Integration. Journal of Common Market Studies. 1996. № 34(2). P. 283-295.

7. Lord C. Utopia or dystopia? Towards a normative analysis of differentiated integration. Journal of European Public Policy. 2015. № 22(6). P. 783-798. URL: https://doi.org/10.1080/13501763.2015.1020839 (дата звернення: 21.12.2018)

8. Blockmans S. The EU's modular approach to differentiated integration: An inclusive, ambitious and legally binding PESCO? Common Market Law Review. 2018. № 55(6). P. 1785-1826.

9. Chopin T. \& Lequesne C. Differentiation as a double-edged sword: member states' practices and Brexit. International Affairs. 2016. № 92(3). P. 531-545.

10. Leruth B., Gänzle S. \& Trondal, J. Differentiated Integration and Disintegration in the EU after Brexit: Risks versus Opportunities. Journal of Common Market Studies. 2019. № 57(6). P. 1383-1394.

11. Cardwell P.J. The End of Exceptionalism and a Strengthening of Coherence? Law and Legal Integration in the EU Post-Brexit. Journal of Common Market Studies. 2019. № 57(6). P. 1407-1418. 
12. Featherstone K. The EU and its Neighbours: reconciling market access, governance, and democracy. Dahrendorf Forum Working Paper. 2017. URL: https://www.dahrendorf-forum.eu/news/new-paper-by-kevinfeatherstone-looks-at-the-eus-relationships-with-its-neighbours/ (дата звернення: 17.01.2021)

DOI https://doi.org/10.30525/978-9934-26-045-2-7

\title{
THE COMPETENCY MODEL OF PUBLIC DIPLOMACY \\ IN THE SYSTEM OF UKRAINIAN PUBLIC ADMINISTRATION
}

\author{
Mostova D. Yu. \\ Postgraduate Student at the Department of Parliamentarism \\ and Political Management \\ National Academy for Public Administration under \\ the President of Ukraine \\ Kyiv, Ukraine
}

It is necessary to make clear what competence and competency mean in the discussion of the professionalization of evaluators. The concept of competence can be traced as a body of knowledge, skills, experience and attitudes / values [1, p. 9]. In contrast, competency is a more concrete concept to include particular knowledge, a single skill or ability, and attitudes. It speaks to the quality of being adequately or well qualified, physically and intellectually [2, p. 18]. Actually, the competency is a guideline developed by a Human Resource department that sets out the specific skills, knowledge and behavioral requirements that enable an employee to perform their job successfully. Competency models define what performance success should look like within the organization for each individual job. The model is applied to recruitment practices, talent management, training and performance assessment [3]. We're mentioned to the necessity of providing competence model in Ukrainian system of public administration, because the competency model provides specific behaviors that an employee must do on the job in order to be successful.

By the way, the Competency model of Public diplomacy ought to be contain in the Strategy of Public Diplomacy, but it's absent in our public system. So as the Strategy not got ready yet, we construct our Competency model of Public diplomacy: there are 3 competency group and 22 competencies as well and of course guidelines for definitions. 